\title{
War, religion, and white supremacy in comparative perspective: South Africa and the American South
}

\author{
R Müller* \\ (University of Pretoria)
}

\section{ABSTRACT}

\section{War, religion, and white supremacy in comparative perspective: South Africa and the American South}

The southern states of the United States of America and South Africa share a number of analogous historical realities. One of these, which is the main subject of this article, is the way in which the memory of a lost war had fused cultural mythology and religious symbolism to provide a foundation for the formation and maintenance of attitudes of white supremacy in both contexts. This article seeks to achieve a historical understanding of the complex interrelationship between the development of cultural identity and Protestant Christianity by focusing on these issues in the histories of the Afrikaner and the white American Southerner in comparative perspective.

\section{INTRODUCTION}

This article attempts a comparative analysis of the relationship between religion and attitudes of white supremacy in two contexts: the American South and South Africa. A basic premise of this article is that the cultural identities of white Southerners and the white Afrikaners ${ }^{1}$ of South Africa were profoundly influenced by two comparable war experiences, the Civil War (1861-1865) in America, and the Anglo-Boer War (1899-1902) in South Africa. Both Southerner and Afrikaner lost their respective wars, and in both cases these wars lived on in the collective imaginations of the

* Retief Müller is currently a PhD-student at the Princeton Theological Seminary, USA. He is also a research associate for Prof $\mathrm{J} C$ Müller of the Department of Practical Theology, University of Pretoria.

1 This group of people of mainly Dutch descent is often designated by the term Boers (literally translated it means farmers). However, the term Afrikaner is more accurately used in conjunction with the period after the outbreak of the Anglo-Boer War in 1899, when most Dutch speaking people in southern Africa identified themselves with the cause of the Boer republics - the Transvaal and the Orange Free State. This awareness of identity eventually gave rise to "Afrikaner Nationalism," which became the driving force behind the political ideology of Apartheid that ruled in South Africa through much of the twentieth century - cf Hexham (1981:6). 
two groups of people. It is, then, specifically the way the collective memories of these war experiences became mythologized that is at stake here. This article will also illustrate how Protestant churches in both contexts were deeply involved in the creation and Christian interpretation of these cultural myths.

The interrelationship of war, religion and group identity seems to be a highly significant, although perhaps under-researched, historical theme that applies to many contexts. For instance, in a comparative study of the English Civil War, the Spanish Civil War, and the American Civil War, Charles Reagan Wilson makes the statement that "religion's overall role in these civil wars was to promote nationalism" (Wilson 1998:400). Thus, even though people might have understood their faith to be something distinct from their cultural identity, the "cultural captivity" of churches was part and parcel of the war experience. This is something that also the American South and Afrikaner South Africa shared with each other. Since the idea of white supremacy at times also strongly influenced both groups of people's self-understandings, the question would be: how did religion and white supremacy inform one another in the American South and Afrikaner South Africa in their post-war contexts? Given the scope of this study there seems to be required a dialectical relationship between, a widening research focus on the one hand to engage the relevant sources of both contexts, which then have to be balanced by a narrowing down on the specific points of interest - race, religion, and war.

\section{ON WAR AND RELIGION}

In the introduction to his book, Baptized in Blood: The Religion of the Lost Cause 1865-1920, Charles Wilson comments on the significance of the phrase "baptism in blood" in the religious vocabulary of the Civil War South:

In his sermon "Our National Sins", preached on November 21, 1860, before Lincoln's inauguration, the distinguished Presbyterian theologian James H Thornwell called for secession, even though "our path to victory may be through a baptism of blood". In 1862 the Episcopal Bishop Stephen Elliot observed, "All nations which come into existence at this late period of the world must be born amid the storm of revolution and must win their way to a place in history through the baptism of blood". "A grand responsibility rests upon our young republic", said the Episcopal rector B T Lacy in 1863, "and a mighty 
work lies before it. Baptized in its infancy in blood, may it receive the baptism of the Holy Ghost, and be consecrated to its high and holy mission among the nations of the earth" (Wilson 1980:4-5).

This understanding of war as a ritual of consecration was also present in Afrikaner religious thought during the Anglo-Boer War (1899-1902), as the following excerpt from a sermon preached by a Dutch Reformed minister as quoted in De Fakkel (February 1900) illustrates:

"God led us into war; it is to chastise us, but he has His sacred goal... He will not let us perish, but will confirm us through this baptism of fire. The Lord Himself planted us in South Africa and let us flourish.... [Like Israel] we are going through the Red Sea, but it will make us into a separate people" (Du Toit 1994:136).

Instead of the "baptism of blood" experienced by the Southerners, the Afrikaner, according to this minister, went through a "baptism of fire", but the similarities are evident. Both "baptisms" are linked to the question of war, either in anticipation or actual experience. Furthermore, it seems that both groups of people understood their group identity to be intimately linked to Divine intention. They understood themselves to be specifically chosen for something, whether this is for a "high and holy mission", or simply to be a "separate people". Despite the obvious similarities we might already infer some differences from these quotations in terms of the their communal self-understanding, the most important, perhaps, being that the Southern "mission" seems to have an outward focus, while the Afrikaner's "separate people" motive appears to be focused distinctly inward. An interesting question, to be addressed later, is whether the two versions of white supremacy as developed on the two contexts exhibited the traits of these self-understandings? But first we have to ask, what was the connection, if any, between race and religion?

With regard to the American South, it is interesting to hear Wilson argue that race, although closely related to the story of the lost cause in the South, "was not the basis of it, was not at the center of it" (Wilson 1980:12). In fact, Wilson, perhaps surprisingly, allots only one chapter to the question of race in his book. For him the main concern of religion in the American South was to offer, "confused and suffering Southerners a sense of meaning, an identity in a precarious but distinct culture" (Wilson 1980:13). From this perspective it would seem that Southerners' racial attitudes formed only a part of that set of values that could be designated 
"a Southern Way of Life" (Wilson 1980:12), as perpetuated in the Cult of the Lost Cause.

There is, however, another and in my opinion a more accurate perspective on this. In his book Race and Reunion: The Civil War in American Memory, David W Blight has eloquently argued for the centrality of race, specifically white supremacy, in the Lost Cause narrative, a fact which was subsequently repressed in the collective memory of the Civil War, up to the point where some even denied that the South's attachment to slavery had anything to do with it ${ }^{2}$. Thus, while Wilson could claim that the Lost Cause was really about that "Southern Way of Life" and not explicitly about race, Blight seems to suggest that such a way of life could only exist in a system of white supremacy. Blacks could never be fully emancipated in that so-called "Southern Way of Life". Blight says:

"Black people would eventually have a place in the Confederate narrative, but only as time-warped, loyal antebellum slaves. In the Confederate version of the story, blacks would have to stay in the past, frozen in time, so that ex-Confederates could take their sick souls to a safe place for rehabilitation" (Blight 2001:79).

Thus, while the exact place of race in the Cult of the Lost Cause seems to be a matter of contention, perhaps even denial in some instances, the perspective presented by Blight is very convincing. From this point of view, the Cult of the Lost Cause was all about race, although this was not necessarily a publicly acknowledged fact. In the case of the Afrikaner, on the other hand, race was always at the forefront. Their racism was of an explicit, rather than an implicit nature. Its no coincidence, for instance, that the term "separate people" as used in the above quote by Du Toit has very little ambiguity to it.

What seems, however, to be very similar between the two cases is the fact that the representative Protestant denominations in both contexts remained closely tied with the respective cultural complexes in which they functioned. Wilson states:

2 For instance, Robert E Lee the grandson and namesake of the famous general argued: "If the South had been heeded, slavery would have been eliminated years before it was. It was the votes of the southern states which finally freed the slaves" (Blight 2001:283). 
"At times, it is clear, the churches have been in "cultural captivity", rather than maintaining a judgmental distance, to southern values. The ties between religion and culture in the South have actually been even closer than has so far been suggested. In the years after the Civil War a pervasive southern civil religion emerged. This common religion of the South, which grew out of Confederate defeat in the Civil War, had an identifiable mythology, ritual, and organization" (Wilson 1989:170).

Blight is even more direct about this cultural dimension of Southern Christianity. Concerning the Lost Cause he says that "for many Southerners it became a natural extension of evangelical piety, a civil religion that helped them link their sense of loss to a Christian conception of history" (Blight 2001:258).

As far as Christianity and Afrikaner culture goes, the linkage, if possible, seems to be even closer than in the South. Du Toit describes the situation as follows:

“...a series of political traumas, from the Jameson Raid of 1895 to the Anglo-Boer War of 1899-1902, forged even closer links between the Dutch Reformed church and an emergent Afrikaner nationalism. The transition of the Dutch Reformed Church into a volkskerk was clearly consolidated in the course of a series of searching synodical and public debates defining the church's relation to the Afrikaner Rebellion of 1914" (Du Toit 1994:130).

The term volkskerk literally translated means people's church, or even ethnic-church. Thus, while Christianity and Southern culture openly supported each other, and while Christianity exhibited a clear cultural dimension that some scholars, such as Wilson and Blight refer to as a "civil religion", in Afrikanerdom this mutual support went a step further. There appears to have been a complete blurring of boundaries not only between religion and culture, but perhaps even more significantly between religion and ethnicity. Therefore, Afrikaner Christianity was for all practical purposes a religion of a specific ethnic group.

What we have to remember at this point is the fact the Afrikaner not only considered themselves to be "separate" from the African population, but also from the British immigrants, and in fact all other immigrants. A contributing factor to this highly differentiated understanding of their identity is the fact that they spoke a different language from all the other 
immigrants. Therefore, while white Southerners in America shared some characteristics with their Northern counterparts, including language, a common Anglo-Saxon heritage, and the same religious traditions, the Afrikaner increasingly came to understand themselves as totally unrelated to the British. This difference is important, because the common heritage between Northern and Southern whites in America perhaps helped Southerners to more easily achieve their "reunion" with the North, while at the same time remaining victorious over Reconstruction. Blight describes this situation as follows:

"By the turn of the century the reunion was all but a fully completed political fact, and the short adventure of the Spanish-American War helped solidify it. But the Southern terms from which the reunion drew its life had to be defended at all costs. White supremacy, a hardening of traditional gender roles, a military tradition and patriotic recognition of Confederate valor, and a South innocent of responsibility for slavery were values in search of a history; they were the weapons arming the fortress against the threat of populist politics, racial equality, and industrialization" (Blight 2001:291).

Thus, the Cult of the Lost Cause played an important role not only in absolving Southerners from any guilt, it also sought to convince Northerners. As such, it had a great amount of export value. Since the clergy were the ones articulating the Lost Cause narrative (Wilson 1980:33-5), we might conclude that religion played a role of reconciliation, although this was a reconciliation restricted to the whites of both sides. In South Africa, religion did not acquire the function of reconciliation or reunion among whites, after the war. If anything, the "separate people" identity of the Afrikaner gained steam. Du Toit says that the representative churches of the opposing parties became increasingly polarized: "the Dutch Reformed church and the Anglican Church, which prior to the war had maintained close and cordial relations that at one point had led almost to church unity, drifted irrevocably apart as each identified with one of the two parties in the war" (Du Toit 1994:135). In the postwar years as the Dutch Reformed church increasingly became involved with Afrikaner nationalism, poor relations with the "English" churches continued to be the status quo. An example of how Afrikaner and English churches continued to drift apart could be seen fact that in the 1920's the volkskerk, which had been deeply involved in general education since before the war, now became a strong advocate for exclusively Afrikaans education (Moodie 1975:69-71). 
However, despite the somewhat different functions of religion in the two contexts under discussion it is clear that attitudes of white supremacy continued to shape the post-war ideological landscape in both South Africa and the American South. The next section directly addresses this theme.

\section{WHITE SUPREMACY ON TWO FRONTS}

In his book White Supremacy: A Comparative Study in American and South African History, George M Fredrickson states that more than other societies that arose in the wake of European colonial expansion, South Africa and the Southern United States "have manifested over long periods of time a tendency to push the principle of differentiation by race to its logical outcome - a kind of Herrenvolk society in which people of color, however numerous or acculturated they may be, are treated as permanent aliens or outsiders" (Fredrickson 1981:xi-xii).

In the South African case this attitude stretched back to the frontier life-style of their predecessors the voortrekkers. It was similar to the conviction prevalent in the Old South that whites had an "inherent right" to rule it over dark skinned people. "But unlike southern secessionists, the voortrekkers had no commitment to slavery as the only effective means of racial control... what they wanted was de facto power rather than a slave code". According to Fredrickson, describing the difference between the two racial points of view basically requires "juxtaposing a highly developed and relatively sophisticated ideology with a set of communal beliefs that barely reached the level of articulate expression" (Fredrickson 1981:172).

There are two basic reasons why these Boer ancestors on the South African frontier did not articulate a racist ideology to support their beliefs. Firstly, their generally low level of education and even basic literacy effectively prohibited them from doing so, but secondly, even had they been highly educated, they still would have had no urgent motive to take such a step. While Southern secessionists had to justify their practices to a wider context of strong opposition, for the Boers "it was usually enough to rely on the common white perception that Africans were actual or potential enemies and so clearly alien in culture and habits that the idea of assimilating them into white society was unthinkable" (Fredrickson 1981:178). A major reason why this "common white perception" could persist unchallenged is the fact that unlike the Southern United States context, in 
southern Africa whites were vastly outnumbered by Africans ${ }^{3}$. Furthermore, even when they identified themselves with the Biblical Israelites, the Boers were conscious of the fact that they were invaders of land occupied by Africans. They were the intruders and their very presence in the land spelled conflict with the Africans. While slavery could be abolished in the American South without completely jeopardizing the status quo of white rule, white supremacy was always in a precarious position in South Africa due to whites' numerical minority status.

Despite the fact that emancipation of slaves in the Southern States posed no direct threat to white rule, it did, of course, create the potential for some major changes in terms of the economic, and social order. Therefore, new methods of control were subsequently invented. While the South African and American "road to reunion" after the two wars was in many ways different, Fredrickson says, "it was similar in its ultimate betrayal of black hopes and aspirations" (Fredrickson 1981:191).

In the American post-Reconstruction period "the growth of legalized segregation and disfranchisement in the South could be a burden on the conscience unless it could be viewed as part of an evolutionary process that would result in an eventual improvement of the black situation". Since even the most prominent black spokesman of the times, Booker $\mathrm{T}$ Washington, seemed to be in agreement with the idea that a period of apprenticeship was needed before blacks could attain full political equality, "it became easy for 'progressive' Northerners to endorse the idea that southern blacks were not ready for equal citizenship and should for their own good, be subjected for an infinite period to the benevolent guidance of the 'best elements' in the white South" (Fredrickson 1981:

3 According to John W Cell in his book, The Highest Stage of White Supremacy: The Origins of Segregation in South Africa and the American South: "In the American South the ratio of white to black was roughly 2 to 1 . In South Africa it was no better than 1 to 3" (Cell 1982:194). This is, of course, a somewhat sweeping generalization, therefore, also cf. Fredrickson who states: "there have been many times and places in South African history where the ratio of white to nonwhite in the areas under direct European rule was not so different from that in parts of the United States, particularly the Deep South" (Fredrickson 1981:xxii). On the other hand, he concedes: "The ratio of white settler to indigenous nonwhite population is such an obvious and enormously significant difference between the American and South African situations as they developed historically that it can never be disregarded (Fredrickson 1981:xxi). 
190-1). Thus white supremacy became sanctified as a kind of paternal supervision.

As described above there was no question from the white South African point of view that the Africans had to be ruled. There was, however, a difference of opinion between the British and the Boers on how that should be done. While the British had a trusteeship policy that promised the protection of conquered African tribes and that allowed them to retain much of their original territory, the Boers had a system called: "Baasskap - which in essence meant direct domination in the interest of white settlers without any pretense that the subordinate race was being shielded from exploitation or guided toward civilization" (Fredrickson 1981:193). While the major British grievance, and main incentive for the Anglo-Boer War, was the denial of political rights to British immigrants who had poured into the Witwatersrand after the discovery of gold in 1886, "British protests and propaganda directed at the Transvaal in the 1890s sometimes used accusations of the mistreatment of Africans and, more particularly, of discrimination against nonwhite British subjects (Cape Coloreds and Indian immigrants) to strengthen a case that republican independence was an affront to Anglo-Saxon principles of justice and equality" (Fredrickson 1981:194).

However, when Britain won the war and the two Boer republics for a brief period became Crown Colonies, "no serious effort were made to reform or modify the pre-existing policies of racial proscription; and when both colonies were granted responsible self-government in 1907, the whites-only franchise remained in effect" (Fredrickson 1981:195).

In the South African case there was no illusion that blacks would be put under a form of "apprenticeship" or "benevolent guidance" that would lead to their eventual political equality. This was very different from the American scenario. However, the British government's "hasty retreat from earlier commitments to equal rights..., strongly resembles the North's failure to enforce black suffrage and civil rights in the South after Reconstruction" (Fredrickson 1981:196). Describing the South African situation John W Cell puts it as follows:

"Peace, however, did not entrench "liberal" British values. Instead, beginning with the treaty of Vereeniging, which pledged that an African franchise would not be a necessary condition for full selfgovernment in the Afrikaner republics, it compromised them. Peace 
meant not increased protection and a widening role for loyal Africans but appeasement of the rebellious Afrikaners" (Cell 1982:266).

Thus, not only did the British neglect their promises to the Africans, but they all but handed power back to the Boers when, after bringing the two rebel republics back under the umbrella of the Empire by means of the Act of Union that was passed in the British Parliament in 1907, power was transferred to the autonomous Union of South Africa in 1910. In other words the entire area of white settlement, which included the colonies of Natal and the Cape, were brought under one rule, which were then quickly granted self-government on the model of other colonies like Canada or Australia. The Boers were now united with their fellow Dutch speakers in other parts of South Africa and together this group that would increasingly become known as the Afrikaner formed the majority of the South African whites. For this reason, the first prime minister of the Union was an Afrikaner, General Louis Botha, who also happened to be a celebrated hero of the Boer War (Cell 1982:61).

Therefore, the two lost wars did not necessarily mean two lost causes. In the South African case something very different was afoot:

"For practical purposes, the Union of South Africa that emerged from a constitutional convention in 1910 was an independent nation. Although they had lost the war, the Afrikaners had in effect won the peace; for they remained a majority of the total white population and had the potential capacity, if they could mobilize themselves politically, to establish their ethnic hegemony" (Fredrickson 1981:138).

From this perspective, the Afrikaner war experience actually really formed the beginning of their cultural formation. Their lost war did not precipitate a lost cause. The lost war did, however, help to shape the nature of the cause that was in the process of becoming. On the surface it looks like the situation in the American South were very different. They lost fair and square, and never regained complete sectional independence. They looked with longing to, and at times attempted to recreate a past way of life that really had come to an end, at least in theory. In practice, the post-war race policies in the two regions proved to develop more analogously. Once slavery was abolished and the economic dominance of the North over the South was established in America, major concessions were made to 
Southern white supremacists ${ }^{4}$. Similarly, after the British victory had unified South Africa and the way had been opened to a free expansion of their capitalist interests, "they found it expedient to give the white inhabitants of the ex-Republics a free hand to rule over blacks more or less according to the settlers' own traditions" (Fredrickson 1981:139). to Cell:

In the American South Reconstruction was but an interval, according

"Beginning in the late sixties and culminating in the fateful compromise of 1876-7, the white South regained control. The South's regional autonomy - in the quaint religious terminology that came to characterize Southern history - was "redeemed". Tired and cynical, the North withdrew its soldiers. Republicans were overwhelmingly replaced in office by patriotic whites, usually called Conservatives, who virtually to a man were former rebels" (Cell 1982:85).

An important difference between South Africa and the American South was that after 1910 the former was a sovereign state. While its economy for long thereafter remained structurally linked to that of Britain, Cell points out that this was not to the same extent that the South's was linked to the North's in America. Apart from the fact that the white population in South Africa was a minority, they were also ethnically divided between Afrikaners and English speakers. What the two contexts did have in common, however, is that both were "white man's countries that had inherited largely vertical patterns of white supremacy, but that developed the primarily horizontal system of segregation as a means of controlling the impact of urbanization and industrialization" (Cell 1982:160-1).

Another distinctive feature between the two contexts that Cell reminds us of is the fact that development of segregation in South Africa was more or less a decade behind America, which allowed the former to learn from the latter. There is some clear evidence that South Africans studied the American experiment closely ${ }^{5}$. While white South Africans

4 Cf Blight (2001) for a good account of how the South, even though they lost the war, successfully managed to resist reconstruction. Considering this, it might perhaps not be too far-fetched to suggest that in many ways they too "won the peace".

5 Among other South Africans, Maurice S Evans made an extensive study in the Southern States of what he termed "the problem of the Twentieth Century... 
were impressed with the pace at which "an African people, albeit one with the 'advantage' of having been schooled in slavery, might become useful, disciplined workers and consumers in an expanding and increasingly sophisticated economy", they were also "appalled by the chronic, explosive violence of the American scene" (Cell 1982:193). Referring to the Southern white churches' support of slavery Maurice Evans wrote in 1915:

"Today there are their descendants, Christian ministers who condone if they do not approve lynching, and who turn to the Scripture to prove that the Negro is, and always will be, an inferior, and attempt thus to justify discrimination and repression" (Evans 1915:67).

Describing some of the alleged reasons for the prevalence of lynching in the South, Evans cites the practice of carrying weapons in many areas that some upheld as a major contributing cause. However, he then states: "[W]e in South Africa are accustomed to firearms, have during the past forty years used them in legitimate warfare far oftener than the Southern people, and yet homicide is not a favourite pastime with either Dutch or English" (Evans 1915:66). Perhaps he is overstating the case, perhaps he is suffering from a case of patriotic blindness to atrocities in his own context, but on the other hand this might be a true difference of serious significance. The fact is that no comparable movement to the Ku Klux Klan emerged in South Africa in the post-war years. One could, of course, argue that such an organization would have been superfluous since the South African police fulfilled their role in the South African context.

Yet, while Evans writes in the post-war era in South Africa, Thomas Packenham makes it clear that during the war years it was the African population that was actually the biggest losers of all. The idea that the Boer War was a "gentleman's war" and a "white man's war" is a complete misconception. While Africans were officially absent from both Boer and British armies, up to a "hundred thousand" were enrolled to serve both sides as labourers, drivers, guides, etc. Furthermore: "Many noncombatants were flogged by the Boers or shot." When the British, who at one point were under siege at a town called Mafeking eventually prevailed, the British commander, Baden-Powell, issued orders by which

the problem of the colour line". His findings were published in 1915 in a 299-page scholarly work: Black and White in the Southern States: a study of the race problem in the United States from a South African point of view. 
more than two thousand of the African garrison "were shot by the Boers or left by Baden-Powell to die of starvation. In general it was the Africans who had to pay the heaviest price in the war and its aftermath" (Pakenham 1979:xxi).

While Evans' confident statement, fifteen years later, that "homicide is not a favourite pastime with either Dutch or English" was in all probability an honest opinion, it is perhaps also a good example of how some details could conveniently get lost in the telling of history. As such we have a romantic recreation of the past, rather than an authentic account of what actually happened. This is where history enters the arena of mythology, a process that occurred often enough in the post-war years in both South Africa and the American South.

\section{THE ROLE OF MYTH IN WHITE SUPREMACY}

\subsection{The South:}

Paul M Gaston (1989:18) says, "one of the ironies of Southern history lies in the simultaneous rise during the 1880's of both the New South creed and the mythic image of the Old South. Sweet 'syrup of romanticism'... flowed over the Old South in the same decade that the New South spokesmen's ideal of a bustling, rich, and reconstructed South captured the American imagination". A contributor to The Confederate Veteran, a certain Ethel Moore, describes what Gaston calls "the orthodox Southern view of the past":

"In the eyes of Southern people all Confederate veterans are heroes. It is you [the Confederate veterans] who preserve the traditions and memories of the old-time South - the sunny South, with its beautiful lands and its happy people; the South of chivalrous men and gentle women; the South that will go down in history as the land of plenty and the home of heroes. This beautiful, plentiful, happy South engendered a spirit of chivalry and gallantry for which its men were noted far and near" (Gaston 1989:21-2).

The power that myth can generate in a culture's discourse is clearly illustrated in the extent to which even the "most influential champion of Negro freedom", Booker T Washington was swept up in the haze when he argued in apparent sympathy with white Southerners in Up from Slavery: "[T]here was an element in the North which wanted to punish the Southern 
white men by forcing the Negro into positions over the heads of Southern whites" (Gaston 1989:25).

While everyone undoubtedly had their own motives for contributing to the mythmaking, Gaston claims that as far as the general effects of the mythmaking went: "it was nationalism rather than sectionalism, and identification rather than a separation, of interests that emerged as benefactors of the myth" (Gaston 1989:25). Thus, "to the South it gave a vitally necessary sense of greatness to assuage the bitter wounds of defeat; to the North it offered a way in which to apologize without sacrificing the fruits of victory" (Gaston 1989:27).

A very interesting and apparently effective feature of Southern mythmaking was to create a picture of "blissful race relations". By softening racist assumptions by means of humor, mythmakers such as Joel Chandler Harris apparently succeeded to some extent "in persuading the North to view the 'quaint darky' through Southern eyes...". This had two important results:

"First, by convincing Northern readers that relations between the races were kindly and mutually beneficial a principle obstacle in the way of sectional harmony was removed. The North had doubted this point, but on the authority of Harris and others it came to accept the Southern point of view. Second, the acquiescence by the North in the Southern scheme of race relations permitted the South to deal with (or to fail to deal with) its race problems unmolested" (Gaston 1989:28).

Convincing the North to leave the South alone, was integral to preservation of the Southern religious cause. John Hope Franklin makes the following telling contrast between Northern and Southern religious outlooks in the antebellum (pre-war) period: "In the North the Transcendentalists advanced the idea of the perfectibility of man, but the emphasis was on how imperfect the social order was. In the South there was general agreement on the depravity of man, but the real emphasis was on how perfect the social order was" (Franklin 1989:103). This social order was one in which the white Southerner's "own sense of superiority was constantly nurtured by the subordination to which he subjected all blacks" (Franklin 1989:106). Therefore an important aspect of their civil religion was to make certain "that the orthodoxy of their churches, 
regardless of denomination, was in perfect harmony with the southern social order" (Franklin 1989:107).

While these were the views of Southerners prior to the war they "saw no reason why defeat at the hands of the North during a bloody Civil War should justify or provide any reason for change" (Franklin 1989:109). The Southern churches that had learned their role well during the antebellum years "continued to function as principal bulwarks against change in the postwar years" (Franklin 1989:110). According to Franklin, Southern clergymen did much to shelter the South from social and religious change by opposing church unity, liberal theology, and any new role for religious institutions in the social order:

"Southern churches could differ, almost violently, over such matters as immersion as opposed to other forms of religious induction, but they were not in conflict over the prime role of the church in preparing its children of God for the next world. Not only should its members be content with the world as it was, but they should be aggressive defenders of the social order as God ordained it. "Organized religion in the South became", as Holding Carter put it, "the mighty fortress of the status quo..." (Franklin 1989:111).

There had to be, of course, a dichotomy in terms of racial attitudes in the minds of many ministers. Charles Wilson says, for instance, "most typically the clerics preached acceptance of Negro inferiority and white supremacy, while working to mitigate the harshness of the system through individual cases of charity and kindness" (Wilson 1980:101). One could perhaps describe this as a kind of spiritual schizophrenia, which often happens in a context when there is a strong cultural subtext that co-exists with the canonized texts of Scripture.

The way such a subtext, or cultural mythology, can sometimes obscure reality by romanticizing the past is illustrated in the irony of the fact that the South "failed to recognize the inherent inconsistencies and contradictions in its argument that it could enjoy a social order that was founded on the exploitation of a group that was an integral part of that social order" (Franklin 1989:117). 


\subsection{The Afrikaner}

In order to understand the role of the pre-Boer War history in the mythology of Afrikaner religion the following assessment by Robert Hamerton-Kelly is helpful:

"Afrikaner group identity was forged between the hammer of British imperialism and the anvil of black resistance. It contains two powerful motivating forces: the sense of being a victim of injustice and arrogance - in this case at the hands of the British - and the exhilaration of being the victor over unfavorable odds - in this instance over the superior numbers of the blacks in battle" (Hamerton-Kelly 1993: 161).

Hamerton-Kelly elaborates on this assessment by naming the two poles of the Afrikaner national myth: "the 1816 rebellion in Cape Colony at Slagtersnek (or Slachter's Nek), which is the victimization pole, and the threehour 'Battle of Blood River' (on the Ncome River in Zululand) on December 16, 1838, which is the victory pole" (Hamerton-Kelly 1993:161).

The Slagtersnek episode went something as follows: in 1816 the British authorities in the Cape Colony hung five Boers at a place in the Eastern Cape called Vanaardtspos for having led an armed rebellion. The reason for the rebellion was that the authorities had sent out a force of blacks to arrest a recalcitrant white man. While the racist rationale went unquestioned by either the British or the Boer version of the event, the mythmakers would later effectively employ it. "The historical details show that the episode was typically ambiguous, but the mythical retelling turned it into an unambiguous instance of British tyranny, exemplified by the fact that the ropes broke in four of the five cases, but the execution went on nevertheless and each of the four survivors was hanged seriatim from the one sound rope" (Hamerton-Kelly 1993:162).

The victory pole, Blood River, provided a firm grounding for the white supremacist element in $20^{\text {th }}$ century Afrikaner mythology. On December 16, 1838, a commando of 468 Boers led by Andries Pretorius defeated a Zulu army of approximately ten thousand strong on the banks of the Ncome River in Natal. The Zulus left three thousand on the field of battle, while only three Boers suffered minor wounds. The Boers renamed the river Blood River, because the water was discolored by the blood of the fallen after the battle (Hamerton-Kelly 1993:165). 
Before the commencement of the battle, this group of Boers had made a "Covenant" with God that if they were victorious they would commemorate that date every year in the future as a special day. According to $\mathrm{Du}$ Toit the commemoration of this day almost immediately fell into disuse until 1881 when it "re-entered public discourse at a national level" (Du Toit 1994:132). From then on the Covenant, interpreted as a sign that God is on the side of the Boers, increasingly gained in importance, and eventually "would become one of the central institutions in the civil religion of modern Afrikaner nationalism, reaching it apogee in the 1930s" (Du Toit 1994:131).

After the War the Boers would increasingly become known as the Afrikaners. Whereas the term Boer specifically designated the descendents of those who took part in the Great Trek, the term Afrikaner was more inclusive of all Dutch-speaking South Africans, and with the unification of the different colonies such an extension of group identity became a powerful political strategy.

Within the context of their self-understanding of simultaneously being victim and victor, Afrikaner nationalism quickly rose to the occasion. So did the language that would become known as Afrikaans. Although it is basically a simplified version of Dutch it achieved higher status when the Bible was translated into Afrikaans. A young Calvinist theologian, J D du Toit (Totius) was primarily responsible for this and other linguistic ventures. Apart from being a Professor of Theology at the Reformed Church's Seminary in Potchefstroom, he was leader of the First Language Movement and the most renowned poet of his time. He more than anyone was responsible for the creation of the national mythology. Irving Hexham says that he and his contemporaries, "simultaneously created their myth and the written language in which that myth was enshrined" (Hexham 1981:33).

One of Totius most famous poems Vergewe en Vergeet (Forgive and Forget) tells the story of a young thorn tree growing beside a road. One day a large wagon appears and one of its wheels overruns the small tree bending it low and severely damaging it. The tree is not uprooted and in time begins to grow again. As it does so, the scar caused by the wagon remains and, with the passing of time, although the wound heals, the scar grows. The poem has a clear message. The thorn tree represents the Afrikaner People and the wagon the British Empire. "After all they had 
experienced at the hand of the British, Afrikaners could never forgive and forget" (Hexham 1989:35).

In his article Afrikaner Civil Religion and the Current South African Crisis, David Bosch interprets the poem Besembos, by Totius. The Besembos is a hardy and resilient semi-desert weed, which Totius makes the symbol of the Afrikaner people. The Besembos flourishes where most other stronger plants would die. Even if you burn it down it just sprouts forth anew and flourishes as before. Bosch states:

"These and other poems became a lens through which Afrikaners were looking upon their past. They conveyed to generations of Afrikaners the notion that they are there to stay, that they are irrevocably part and parcel of the soil of Africa, of the veld and the mountains and the rivers, and that no earthly force would ever succeed in subduing them, let alone routing them" (Bosch 1988:16).

Totius also made rich use of his biblical knowledge to draw comparisons between Israel and the Afrikaner. His poems are filled with references to the Afrikaner people as the suffering servants of God. Potgieter's Trek describes one aspect of the Great Trek as an epic pilgrimage filled with much hardship, making the connection with Israel's exodus from Egypt. Hexham makes the following comments about this poem and thereby cuts to the core of Afrikaner religious self understanding:

"Like Israel, and following the example of Christ Himself, the Afrikaner People achieve salvation through suffering. Totius' poem is therefore a psalm to national deliverance, an interpretation of history that makes the past bearable. The irrational pattern of past events fits into a divine scheme, which removes their arbitrary appearance and eternally legitimates them" (Hexham: 1981:41).

It is quite ironic that they, who considered themselves the suffering servants of God, the victims of British injustices, could conveniently forget that they were in reality the real oppressors, the ones responsible for the greatest amount of suffering in South Africa. The fact that this could happen would not make sense without an understanding of the powerful role played by religion in the formation of Afrikaner identity. As was the case in the American South, we can clearly discern a strong cultural subtext that not only co-existed with, but also actually informed Afrikaner interpretation of Scripture. In the imagination of the people these two "texts," perhaps inevitably, became merged into one, evolving into a 
cultural mythology of redemptive suffering, chosenness, and Divine destiny.

\section{SYNTHESIS OF SIMILARITIES AND CONTRASTS}

According to David Blight: "The study of historical memory might be defined, therefore, as the study of cultural struggle, of contested truths, interpretations, moments, events, epochs, rituals, or even texts in history that thresh out rival versions of the past that are in turn put to the service of the present" (Blight 2001:120-1). In other words, with historical memory it is often the present that set the agenda of what the past should look like. Moreover, this version of the past are then perceived to have a certain value, whether that is as a legitimization for the preservation of the status quo, or as a prescriptive model for how and when change should occur. It is the value that is attributed to a specific version of history that could elevate it to the plane of sacred history. When such a sacred history becomes the official or dominant history it often takes on a totalitarian nature, making every conceivable effort to discredit other versions of the same history.

Both American Southerners and Afrikaners in South Africa were the protagonists of their own sacred histories. This understanding of having a sacred history is clearly illustrated, for example, in the above-described resistance to social change in the American South. The idea that the antebellum (pre-war) social order was somehow something which God had ordained would effectively have cut the wings of any Scriptural interpretation that would seek to emphasize the prophetic dimension of the Biblical narrative. Old Testament texts such as Jeremiah, for instance, that severely criticize the social order would either be completely ignored or otherwise re-interpreted to the extent that it would become an entirely new text with a new message. This means that the Biblical text actually becomes subordinate to the cultural subtext, although this subordination obviously remains unacknowledged. The Biblical text is then allowed to inform the conscience only to the extent that it doesn't threaten or disturb the all-important social order. The fierce and often violent opposition to the civil rights movement in the 1960 s by Christian white Southerners to the social demands of Christian African Americans is a good example of how deep the subtext were ingrained by this time.

Afrikaner sacred history found its legitimacy in the Day of the Covenant, described above, and its ritual annual celebration. In the 
historical clash of the black Zulu and the white Afrikaner, it was believed that God had proven himself to be on the side of the Afrikaner. While the American South might have had a "God ordained" social order, the Afrikaner considered themselves to be an ordained people. The social order might change, but the Afrikaner as a people would not lose their identity. Since their identity depended on their continued victory over the black majority, they realized that they too had to control the social order, hence the need for a comprehensive political system to achieve that. This desire resulted in the comprehensive and elaborate system of Apartheid. Therefore, unlike the situation in the American South where Jim Crow laws were aimed at recreating the antebellum social order as far as possible, the intention with Apartheid was not so much preserving the past, but rather insuring the future.

When a Judeo-Christian people creates a sacred history it is perhaps inevitable that they will strongly identify with the Biblical Israel, especially when they understand themselves to be suffering for a cause. The hardships that the Afrikaner suffered during the Great Trek and the military defeat at the hands of the British in the Anglo-Boer War was correlated to the hardships suffered by Israel during their forty years stint in the Wilderness following the Exodus. All these chastisements were necessary preparations before the long-awaited entrance into the land "Canaan" could occur. For the Afrikaner Canaan finally became a reality when after the institution of Apartheid the "heathen" black tribes could, according to the homelands act, be forcibly removed to their designated "home" areas.

American Southerners also compared themselves with Israel. Wilson mentions one Lost Cause minister who claimed, "[T] he army had been protecting a Southern Ark of the Covenant, just as the biblical chosen people did in their wanderings" (Wilson 1980:43). While Wilson does not elaborate on what this "Ark of the Covenant" might have referred to it is perhaps safe to assume that the analogy is to that "Southern Way of Life", that "God ordained" social order, which we heard about earlier. With their victory over Reconstruction Southerners entered, or perhaps re-entered, their own Canaan.

Perhaps this is a good place to re-evaluate the symbolic significance of the Southern "baptism of blood" and the Afrikaner "baptism of fire", because they seem to have been strangely prophetic in the light of what 
eventually happened in both contexts. While both baptisms inspire images of war and suffering we have seen that the Southern baptism was understood as the first step in the process of being "consecrated to its high and holy mission...". The Afrikaner baptism on the other hand, had the eventual goal of becoming a "separate people". History shows the evidence that both groups had, for a time at least, achieved the purpose of their "baptisms". The South, with their ideological victory over Reconstruction, successfully convinced enough Northerners of the rightness of their cause to perpetuate their "Southern way of life". Therefore, they achieved their mission. The Afrikaner, as we know, did also become a separate people; so separate, in fact, that for more than forty years they successfully isolated and insulated themselves from a rising tide of negative world opinion.

While white supremacy was the cornerstone of how both societies operated, the way it functioned differed to some degree within the two contexts. The Afrikaner's goal -separateness, although not easy to achieve within the plural African context, was relatively uncomplicated. All they had to do was to convince themselves of their own chosenness and at the same time be scared enough of the very real possibility that the African masses might rise up in vengeance against their oppressors, and the proverbial circling of the wagons were virtually a forgone conclusion. Racism inspired by fear was the fuel on which Afrikaner white supremacy thrived. Afrikaner white supremacy was deeply rooted in the insecurities brought about by the knowledge of the precarious nature of their identity as the only white tribe in Africa. Therefore, their white supremacy was not apologetic, nor was it camouflaged as something else. From their point of view, they were the embattled protectors and representatives of Christianity and "Civilization" in darkest Africa.

For the Southerners to be able to fulfill their "mission", they had to convince the world and particularly the North to see the situation from their point of view. This was a far trickier situation from what the Afrikaner had to deal with. While the latter received only token opposition, and actually mostly silent support from the English speaking white population who had just as much reason to fear the African masses, white Southerners in America had to convince a majority of skeptical Northerners that their "Way of Life" was really quite harmless and actually beneficial for the well-being of African Americans. Therefore, their myth-making, having export value, had to be far more extensive and 
creative than what the Afrikaner had to come up with. Someone like Joe Chandler Harris had to use subtle techniques, such as the employment of humor to soften racist assumptions and so make the Southern cause more presentable, and ultimately more acceptable to Northern audiences. Furthermore, the creation of the myth of the "faithful slave" (Blight 2001:284-ff) was an essential aspect of their "mission". In short, the South had to put much more work into the maintenance and advertising of their ideology than the Afrikaner. They had to trick their own country folk into believing that they were benign benefactors, rather than racist white supremacists.

These differing approaches to white supremacy might have had some lingering effects on the two contexts that have not fully worked themselves out, yet. For instance, while white supremacy as a political manifestation in South Africa is happily something of the past, overtly racist sentiments are as prevalent among Afrikaners as ever. While most Afrikaners no longer believe that whites are destined to rule blacks in Africa, and while they mostly no longer seek religious explanations for a racist rationale, many are quick to blame personal misfortunes, and the poor state of the economy on the "incompetence" of the black government, etc.

Also in the American South, segregation is a long-gone memory of a distant era. White supremacy is a buried concept, or is it? The controversial statements made by the previous United States Senate Majority leader, Trent Lott, a year ago regarding his admiration for the old segregationalist, Strom Thurmond, made one wonder whether this ideology is really as dead as people like Lott himself would want us to believe. In some of the arguments presented above we saw that it was in the interest of the Cult of the Lost Cause to present a picture of "blissful" race relations, when in reality nothing had changed. When people like Lott and his supporters vehemently argue that they have changed, that they no longer believe in the tenets of white supremacy we should perhaps be willing to accept their explanations, but on the other hand our historical hindsight makes it very difficult for us to refrain from asking whether it is not the same old game of the Lost Cause all over again?

\section{Consulted literature}

Blight, David W 2002. Beyond the Battlefield: Race, Memory, and the American Civil War. Amherst \& Boston: University of Massachusetts Press. 
-, 2001. Race and Reunion: The Civil War in American Memory. Cambridge: The Belknap Press of Harvard University Press.

Bosch, David J 1988. "Afrikaner Civil Religion and the Current South African Crisis." Colloquium: The Australian and New Zeeland Theological Review 20(2), 12-23.

Cell, John W 1982. The Highest Stage of White Supremacy: The Origins of Segregation in South Africa and the American South. New York: Cambridge University Press.

Du Toit, Andre 1994. The Construction of Afrikaner Chosenness, in Hutchison, W R \& Lehmann, H (eds). Many are Chosen: Divine Election and Western Nationalism. Minneapolis: Fortress Press, 115-140.

Evans, Maurice S 1915. Black and White in the Southern States: a study of the race problem in the United States from a South African point of view. London: Longmans, Green and Co.

Franklin, John Hope 1989. The Great Confrontation: The South and the Problem of Change, in Gerster, P \& Cords, N (eds). Myth and Southern History, Volume 2: The New South, second edition. Chicago: University of Illinois Press, 101-140.

Fredrickson, George M 1981. White Supremacy: A Comparative Study in American and South African History. New York: Oxford University Press.

Gaston, Paul M 1989. The New South Creed: A Study in Southern Mythmaking, in Gerster, P \& Cords, N (eds). Myth and Southern History, Volume 2: The New South, second edition. Chicago: University of Illinois Press, 17-32.

Gerster, P \& Cords, N (eds). 1989a. Myth and Southern History, Volume 1: The Old South, second edition. Chicago: University of Illinois Press.

-, 1989b. Myth and Southern History, Volume 2: The New South, second edition. Chicago: University of Illinois Press.

Hamerton-Kelly, Robert 1993. Biblical Justification of Apartheid in Afrikaner Civil Religion, in Keulman, Kenneth (ed). Critical Moments in Religious History. Macon, Georgia: Mercer University Press, 161-171.

Hexham, Irving 1981. The Irony of Apartheid: The Struggle for National Independence of Afrikaner Calvinism against British Imperialism. New York and Toronto: Edwin Mellen Press.

Hutchison, W R \& Lehmann, H (eds.) 1994. Many are Chosen: Divine Election and Western Nationalism. Minneapolis: Fortress Press.

Keulman, Kenneth (ed.) 1993. Critical Moments in Religious History. Macon, Georgia: Mercer University Press.

Miller, R M, Stout, H S, \& Wilson, C R (eds.) 1998. Religion and the American Civil War. New York: Oxford University Press. 
Moodie, T Dunbar 1975. The Rise of Afrikanerdom: Power, Apartheid, and the Afrikaner Civil Religion. Berkeley: University of California Press.

Pakenham, Thomas 1979. The Boer War. New York: Random House.

Wilson, Charles Reagan 1980. Baptized in Blood: The Religion of the Lost Cause 1965-1920. Athens: University of Georgia Press.

-, 1998. Religion and the American Civil War in Comparative Perspective, in Miller, R M, Stout, H S, \& Wilson, C R (eds). Religion and the American Civil War. New York: Oxford University Press, 385-407.

-, 1989. The Religion of the Lost Cause, in Gerster, P \& Cords, N (eds). Myth and Southern History - Volume 1: The Old South, second edition. Chigago: University of Illinois Press, 169-189. 